\title{
Transcriptional regulation of immunoglobulin $\mathrm{V}$ genes
}

Elizabeth L.Mather and Robert P.Perry

Institute for Cancer Research, Fox Chase Cancer Center, Philadelphia, PA 19111, USA

Received 8 September 1981

ABSTRACT

The relative transcriptional activity of rearranged and unrearranged (germline) $V_{k}$ genes in secreting plasmacytoma cells was assessed by two independent methods. Measurements of $\mathrm{V}$ sequence abundance by hybridization kinetic (Rot) analysis indicated that the steady state content of transcripts from a rearranged $V_{k}$ gene is at least 16,000-fold greater than that from an unrearranged $v_{k}$ gene. Direct measurements of transcriptional activity in isolated nuclei indicated that this difference is due, in large part, to a difference in transcription rate. Since the primary sequences of $\mathrm{V}$ genes and their $5^{\prime}$ flanking regions are not altered during rearrangement, these results suggest that $V_{K}$ gene transcription might be controlled by elements on the $3^{\prime}$ side of the $V_{k}$ genes or at the $C_{k}$ locus, perhaps via an influence on chromatin structure.

\section{INTRODUCTION}

One of the major problems in eukaryotic biology concerns the means by which cells control gene expression. It is clear that transcriptional control is frequently utilized (1), but the mechanisms by which differential transcription is effected are not known. There is evidence that sequences on the 5' side of eukaryotic genes play a role in determining how efficiently genes are transcribed by RNA polymerase II $(2,3)$. For some genes, however, transcription appears to be regulated by sequences on the $3^{\prime}$ side of the initiation site. This has been shown most clearly for polymerase III products $(4,5)$, but in principle could also apply to the products of polymerases $I$ and II as well [cf. (6-8)]. Indeed elements located a considerable distance downstream from the initiation site could affect transcription via their influence on the structural organization of a chromatin domain.

Cells of the B lymphoid lineage provide a novel system for studying transcriptional regulation. Each cell has several hundred copies of $\mathrm{V}$ genes. Although some are known to be pseudogenes $(9,10)$, it is clear that a large number of these genes have the potential to be expressed (11). Yet in a par- 
ticular B cell, the only $\mathrm{V}$ gene sequences that appear in messenger RNA are those from the $V$ genes that have been rearranged in such a way that they are adjacent to a region containing the $C$ gene. Sequence comparisons of active, rearranged $\mathrm{V}$ genes cloned from myeloma tumors and the unrearranged or germline counterparts cloned from nonlymphoid tissue reveal no differences up to 500 nucleotides to the $5^{\prime}$ side of the $\mathrm{V}$ gene (12). Moreover, restriction enzyme mapping and heteroduplex analysis indicate that the homology extends to at least $6.5 \mathrm{~kb}$ of $5^{\prime}$ flanking sequence $(13,14)$. Hence, these rearrangements do not appear to cause any fundamental change in the $\mathrm{V}$ genes themselves or in the regions $5^{\prime}$ to the $\mathrm{V}$ genes. If transcriptional activity were determined solely by the sequence characteristics of the $5^{\prime}$ flanking regions, one might expect unrearranged $V$ genes to be transcribed in cells that are actively transcribing rearranged $V$ genes. On the other hand, if this regulation involved additional elements, this might not be the case. Thus, it is of critical importance to know whether there is any significant transcriptional activity associated with unrearranged $\mathrm{V}$ genes.

Previous RNA-blotting analyses of nuclear RNA from plasmacytoma cells did not detect any transcripts of unrearranged $\mathrm{V}$ genes (15). However, if such transcripts were relatively short $(<0.5 \mathrm{~kb})$, relatively unstable, or polydisperse in length, they would not have been detected in this analysis. Therefore, we have re-examined this question with techniques that are not subject to the above reservations.

\section{MATERIALS AND METHODS}

Mouse myeloma tumors and cell lines

The myeloma cells MPC 11 and $\$ 107.3$ were originally obtained from Drs. M. D. Scharff and D. Margulies. The MPC 11 cell line was maintained as previously described (16); the 5107.3 cell line was maintained in Dulbecco's modified minimal essential medium supplemented with $20 \%$ heat-inactivated horse serum, non-essential amino acids and glutamine. The myeloma tumors PC 4050 and PC 3741, obtained from Dr. M. Weigert, were propagated subcutaneously in $\mathrm{F}_{1}$ (NZB $\times \mathrm{BALB} / \mathrm{c}$ ) mice.

Isolation of nuclear RNA and cytoplasmic poly $A^{+}$RNA

Tumors were homogenized in citric acid and nuclear RNA isolated from the pelleted nuclei by hot phenol extraction (15). The lysate supernatant was centrifuged at $43,000 \times \mathrm{g}$ for $30 \mathrm{~min}$ at $4^{\circ} \mathrm{C}$ and cytoplasmic RNA isolated from the redissolved pellet by extraction with phenol/chloroform (17). Alternatively, polysomal RNA from the tumors was isolated as described by Marcu 
et al. (16). Cytoplasmic RNA from MPC 11 was isolated as described by Schibler et al. (18) and poly $A^{+}$RNA selected by oligo(dT) cellulose chromatography. RNA blots

Polysomal poly $\mathrm{A}^{+}$RNA was incubated at $65^{\circ} \mathrm{C}$ for $5 \mathrm{~min}$ in $50 \%$ formamide, $2.2 \mathrm{M}$ formaldehyde, $0.02 \mathrm{M}$ morpholinopropansulfonic acid, $5 \mathrm{mM}$ sodium acetate, $1 \mathrm{mM}$ EDTA, $\mathrm{pH} 7.0$, and electrophoresed on $1 \%$ agarose gels containing $2 \mathrm{M}$ formaldehyde. The RNA was blotted onto nitrocellulose paper and hybridized to nick-translated V specific probes as described by Thomas (19).

\section{Preparation of single-stranded probes}

Probes for $V_{K} 19$ and $V_{K} 21$ were isolated from the cDNA clones complementary to $V_{K}$ chain mRNA obtained from the myelomas MPC 11 and MOPC 321, respectively. A $260 \mathrm{bp}$ fragment consisting entirely of $\mathrm{V}_{\mathrm{K}} 19$ sequence was isolated by sequential digestion of the plasmid $\mathrm{pk}(11)^{24}$ (18) with Hinc II and Mbo II (20). A 700 bp fragment consisting of 234 bp of $v_{K} 21$ sequence and approximately 460 bp of plasmid DNA was isolated by Hinf I digestion from the $\mathrm{V}$ region subclone of the recombinant plasmid 5D10 (13). The isolated fragments were nick-translated with $(\alpha-32 \mathrm{P}) \mathrm{dCTP}$ and hybridized at $48^{\circ} \mathrm{C}$ in $80 \%$ formamide, $0.4 \mathrm{M} \mathrm{NaCl}, 1 \mathrm{mM}$ PIPES, $\mathrm{pH} 6.4$, to poly $\mathrm{A}^{+}$RNA from MPC 11 or PC 4050 to a Rot of $0.1-0.2$ mole 1 iter $^{-1}$ sec. The reactions contained an 8 to 20-fold excess of complementary mRNA. The reaction mixture was then incubated with S1 nuclease and treated with alkali to destroy the RNA as previously described (16).

DNA-RNA hybridizations

Hybridization reactions were carried out essentially as described by Marcu et al. (16). For hybridizations with nuclear RNA from the $V_{K} 21-$ expressing myelomas, the mass ratio of RNA to DNA was at least $1 \times 10^{6}$ when the $V_{K} 21$ probe was used and was routinely $8 \times 10^{7}$ when the $V_{K} 19$ probe was used. For hybridization to polysomal poly $A^{+}$RNA, the mass ratio of RNA to DNA was at least $2 \times 10^{3}$. The extent of hybrid formation was determined by resistance to $\mathrm{S} 1$ nuclease digestion.

Transcription by isolated nuclei

S107.3 myeloma cells were grown to an average density of $9 \times 10^{5}$ cells/ml. Nuclei were isolated by the procedure of Widnell and Tata (21) except that $0.05 \%$ Triton $\mathrm{X}-100$ was included in the homogenization buffer. The nuclei were suspended in $40 \%$ glycerol, $50 \mathrm{mM}$ Tris- $\mathrm{HCl}, \mathrm{pH} 8.3,5 \mathrm{mM} \mathrm{MgC1}$, $0.1 \mathrm{mM}$ EDTA and stored at $-70^{\circ} \mathrm{C}$. Transcription was carried out using a modification of procedure of McKnight and Palmiter (22). A sample containing $1.8 \times 10^{7}$ nuclei was thawed and incubated for $15 \mathrm{~min}$ at $26^{\circ} \mathrm{C}$ in a $200 \mu 1$ 
reaction mixture containing $20 \%$ glycerol, $0.5 \%$ Sarkosyl, $0.15 \mathrm{M} \mathrm{KCl}, 5 \mathrm{mM}$ $\mathrm{MgCl}_{2}, 1 \mathrm{mM} \mathrm{MnCl} 2,2.5 \mathrm{mM}$ DTT, $0.1 \mathrm{mM}$ EDTA, $10 \mathrm{mM}$ phosphocreatine, $10 \mu / \mathrm{ml}$ creatine phosphokinase, $0.4 \mathrm{mM}$ each of ATP, CTP and GTP, $5 \mu \mathrm{m} \mathrm{UTP}$, and $250 \mu \mathrm{C}$ [ $\left.\alpha-{ }^{32} \mathrm{P}\right]$ UTP (530 Ci/mmole). RNA was isolated as described by Groudine, Peretz and Weintraub (23) except that the initial incubation of the nuclei with DNase was extended to $15 \mathrm{~min}$ and the DNase concentration was increased to $120 \mu \mathrm{g} / \mathrm{ml}$. Analysis of labeled RNA

The $V_{K} 21$ and $C_{K}$ subclones of $5 D 10$ (15) and the plasmid pMB9 were linearized with Bam H1. For dot analysis 15 to $20 \mu \mathrm{g}$ were applied to HAWP 01300 Millipore filters by the procedure of Kafatos, Jones and Efstratiadis (24). For Southern blot analysis the $\mathrm{C}_{K}$ and $\mathrm{V}_{K} 21$-containing plasmids were digested with tha $I$, electrophoresed on $2 \%$ agarose gels and transferred to nitrocellulose filters. RNA isolated from the nuclear transcription reaction was hybridized to the filters using the hybridization conditions and wash procedures described by Groudine, Peretz and Weintraub (23), except that hybridization times were shortened to 2.5 to 3.5 days. The filters were autoradiographed at $-70^{\circ} \mathrm{C}$ with an intensifier screen.

\section{RESULTS}

Strategy and selection of $\mathrm{V}$ genes

Two different methods were used to assess the relative transcriptional activity of rearranged and unrearranged $\mathrm{V}$ genes: a determination of $\mathrm{V}$ sequence abundance in total nuclear RNA by a hybridization kinetics (Rot) analysis (25) and a measurement of polymerase II loading of specific gene segments by a "run-off" transcriptional assay in isolated myeloma nuclei (22). The Rot analysis is very sensitive for detecting minute amounts of transcript of any size, but since it is applied to steady state nuclear RNA, it would underestimate the importance of a highly unstable transcript. The transcriptional assay has a somewhat lower sensitivity, but is much less dependent upon the stability of the RNA products.

For the Rot analyses we selected plasmacytomas PC 4050 and MOPC 321, each of which possesses a rearranged allele that expresses a member of the $\mathrm{V}_{K} 21$ group of $\mathrm{V}$ genes, and an unrearranged (germline) allele that contains the full complement of $V_{K}$ genes (15). As a representative set of unrearranged $V$ genes we chose the $v_{k} 19$ group for two reasons. First, it is known to be 1ocated upstream of the $\mathrm{V}_{\mathrm{K}} 21$ group, and is therefore retained during the rearrangements that give rise to $V_{K} 21$ expression (26). Since the selected plasmacytomas contain a complete diploid set of $v_{K} 19$ genes in the germline 
context, they should maximize our opportunity to detect unrearranged V-gene transcription. Second, the $\mathrm{V}_{\kappa} 21$ and $\mathrm{V}_{K} 19$ groups are distantly related. Their amino acid sequences are only 50\% homologous, and previous solution hybridization studies with $\mathrm{V}_{K} 21$ and $\mathrm{V}_{K} 19$ mRNAs and their respective cDNAs indicated that there is little or no cross-hybridization between them (27). On the other hand, within a group the homology is sufficiently high so that a probe for one member of a group will usually cross-hybridize efficiently with all other members $(27,28)$. Current estimates of gene copy number, based on Southern blot analyses of mouse embryo DNA, are about 8 genes for the $V_{K} 21$ group and 4 to 8 genes for the $V_{K} 19$ group $(13,28,29)$. Preparation of $V$ probes and verification of their specificity

$\mathrm{V}_{K} 21$ and $\mathrm{V}_{K} 19$ specific DNA probes were isolated from the cDNA clones as diagrammed in Fig. 1. Digestion of the $\mathrm{pV}_{K} 21$ (5D10) plasmid with Hinf I gives a 700 base pair fragment containing $234 \mathrm{bp}$ of $\mathrm{V}_{\mathrm{K}} 21$ and approximately $460 \mathrm{bp}$ of plasmid. Digestion of the $\mathrm{pV}_{k} 19$-containing plasmid $\mathrm{pK}(11)^{24}$ with Hinc II yields a 380 bp fragment containing V, J and $\mathrm{C}$ region sequences. Subsequent digestion of this fragment with Mbo II yields a 260 bp fragment containing only $\mathrm{V}$ region coding sequences.

To verify the specificity of these sequences, we labeled the $700 \mathrm{bp}$ $\mathrm{V}_{\mathrm{K}} 21$ and the $260 \mathrm{bp} \mathrm{V}_{\mathrm{K}} 19$ fragments with $32 \mathrm{P}$ by nick translation, and hybridized them to blots of cytoplasmic poly $\mathrm{A}^{+} \mathrm{RNA}$ obtained from the myelomas PC 3741 and MPC 11 which produce $K$ chains of the $V_{K} 21$ and $V_{K} 19$ group, respec-
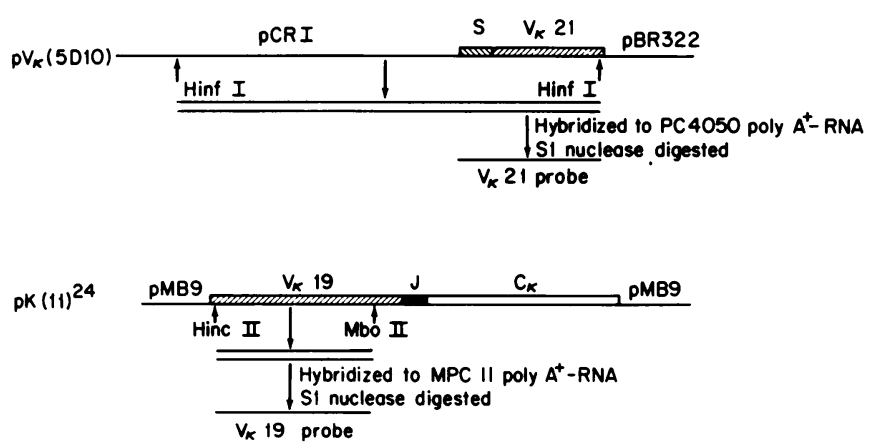

Figure 1 Preparation of the $V_{K}$ specific probes. The recombinant plasmid $p V_{K}$ (5D10) contains sequences encoding the MOPC $321 \mathrm{~K}$ light chain from the second amino acid of the signal peptide (S) through amino acid 61 of the $V$ region; it also contains sequences of the original 5D10 cloning vector PCRI as well as those of pBR322 (15). The recombinant plasmid pk(11) 24 consists of mRNA sequences for the MPC $11 \times$ light chain extending from the codon for amino acid residue 10 through to the $3^{\prime}$ terminus, inserted into PMB9 (18). 


\section{Nucleic Acids Research}

tively (Fig. 2). The $\mathrm{V}_{\mathrm{K}} 21$ probe hybridized to a band of the size expected for kappa chain mRNA in the lane containing PC 3741 RNA whereas no bands were observed in the lane containing MPC 11 RNA. Likewise, the $\mathrm{V}_{K} 19$ probe hybridized to a specific band in the lane containing MPC 11 RNA and no bands were observed in the lane containing PC 3741 RNA.

For the hybridization kinetic analysis the nick-translated $\mathrm{V}$ specific probes were made single-stranded by hybridizing them to homologous mRNA and then treating the hybrids with $\mathrm{S} 1$ nuclease and alkali. The quality and specificity of the single-stranded probes were tested in a solution hybridization assay with homologous and heterologous mRNAs (Table 1). Seventy-three percent of the $V_{K} 21$ probe was resistant to digestion by $S 1$ nuclease following hybridization to poly $A^{+}$RNA isolated from the myeloma PC 4050 , and $94 \%$ of the $\mathrm{V}_{\mathrm{K}} 19$ probe was resistant to digestion following hybridization to poly $\mathrm{A}^{+}$RNA

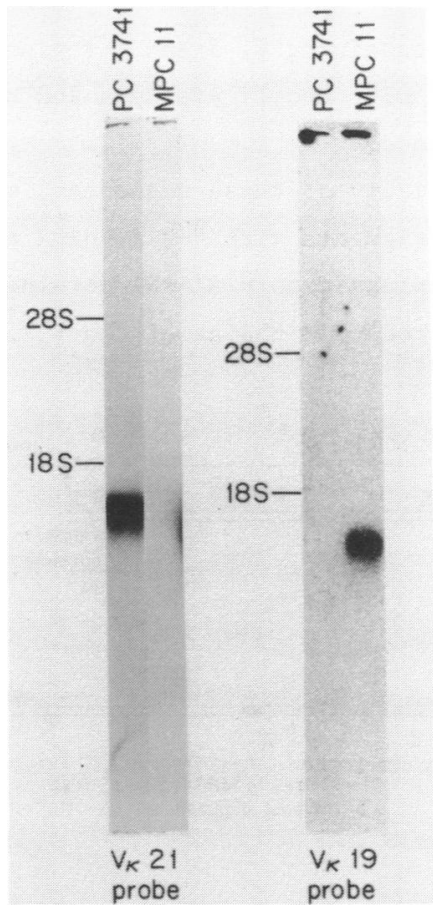

Figure 2 Determination of probe specificity by RNA blot analysis. Samples of poly A ${ }^{+}$cytoplasmic RNA from PC 3741 and MPC 11 were size-fractionated on formaldehyde-agarose gels, transferred to nitrocellulose paper and hybridized with $32 \mathrm{P}$-labeled $\mathrm{V}_{\mathrm{K}} 21$ (a) or $\mathrm{V}_{\mathrm{K}} 19$ (b) probe. In (a) $10 \mathrm{ng}$ of PC 3741 and $20 \mathrm{ng}$ of MPC 11 RNA were used; in (b) $5 \mathrm{ng}$ of PC 3741 and $5 \mathrm{ng}$ of MPC. 11 RNA were used. 
Table 1. Specificity of the single-stranded $v_{K}$ probes

\begin{tabular}{|ccc|}
\hline & Percent hybridized at Rot 36 \\
Probe & MPC 11 & PC 4050 \\
$\mathrm{~V}_{K} 19$ & $901 \mathrm{y} \mathrm{A} \mathrm{A}^{+} \mathrm{RNA}$ & Poly $\mathrm{A}^{+}$RNA \\
$\mathrm{V}_{\mathrm{K}} 21$ & 94 & 0 \\
& not done & 73 \\
\hline
\end{tabular}

Single-stranded $32 \mathrm{P}$-1abeled $\mathrm{V}_{\kappa} 21$ (specific activity $8 \times 10^{7} \mathrm{cpm} / \mu \mathrm{g}$ ) and $\mathrm{V}_{\mathrm{K}} 19$ (specific activity $7 \times 10^{8} \mathrm{cpm} / \mu \mathrm{g}$ ) probes were hybridized with poly $\mathrm{A}^{+}$cytoplasmic RNA in a solution of $0.6 \mathrm{M} \mathrm{NaCl}, 20 \mathrm{mM}$ Tris, $\mathrm{pH} 7.4,2 \mathrm{mM}$ EDTA at $68^{\circ} \mathrm{C}$. The Rot values have been corrected to standard salt concentrations and for self-annealing $\left(6 \%\right.$ for $v_{K} 21$ and $4 \%$ for $\left.\mathrm{V}_{\mathrm{K}} 19\right)$.

from MPC 11. In contrast, there was no protection of the $v_{K} 19$ probe when it was incubated with PC 4050 poly A RNA to a Rot of 36 . Since the Rot $1 / 2$ value for reactions of poly $A^{+}$mRNA with homologous probes is about $1-2 \times 10^{-2}$ (18), we should be able to distinguish sequence abundancies over a range of at least 2000-fold without complications due to cross-hybridization.

Relative abundance of nuclear transcripts from rearranged and unrearranged $\underline{v}$ genes

Total nuclear RNA was prepared from the $V_{K} 21$-expressing tumors and annealed to the $V_{K} 21$ and $V_{K} 19$ probes over a range of Rot values. When the $V_{K} 21$ probe was annealed to nuclear RNA from PC 4050, 50\% of the hybridizable probe was rendered S1-resistant at a Rot value of 5 (Fig. 3). In contrast, when the $\mathrm{V}_{K} 19$ probe was incubated with PC 4050 nuclear RNA, no S1 nuclease-resistant hybrids were observed at Rot values below 1000, and at a Rot value of $10^{4}$ approximately $40 \%$ of the probe was resistant. Increasing the RNA/DNA mass ratio by a factor of two did not increase the amount of probe that hybridized to nuclear RNA (data not shown), indicating that the hybridization was limited by the concentration of complementary sequence but not by the absolute amount. Similar results were obtained when the $V_{K} 19$ probe was hybridized to nuclear RNA from another $V_{K} 21$-producing myeloma, MOPC 321 , and to different preparations of nuclear RNA from PC 4050. By comparing the Rot $1 / 2$ values of the $V_{K} 21$ and $\mathrm{v}_{K} 19$ hybridization curves, it can be seen that $\mathrm{v}_{K} 19$ sequences are approximately 2000-fold less abundant than the $V_{K} 21$ sequences. Because our total nuclear RNA preparations contain some DNA contamination (on the order of a few percent), it is possible that the S1-resistant hybrids formedat the very high Rot values do not actually involve RNA. Therefore, the difference in relative abundance of transcripts from rearranged and unrearranged $V$ genes could be even greater 


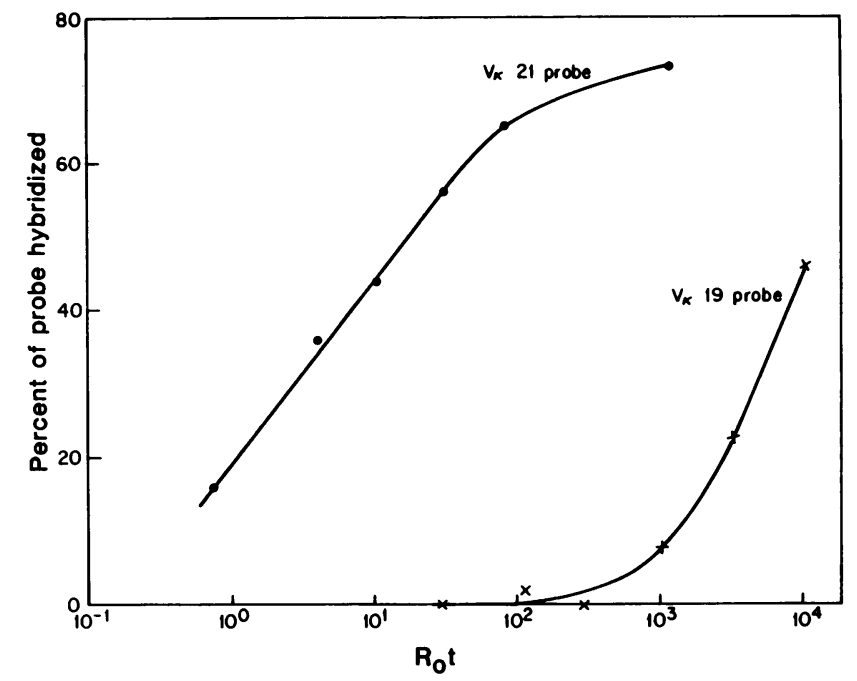

Figure 3 Abundance of $V_{K} 21$ and $V_{K} 19$ sequences in total nuclear RNA of PC 4050. Single-stranded $32 \mathrm{P}$-labeled $\mathrm{V}_{K} 21$ and $\mathrm{V}_{\kappa} 19$ specific probes were hybridized with nuclear RNA from the tumor PC 4050 using the conditions described in Table 1.

than 2000-fold.

In vitro assay of unrearranged $V$ gene transcription

The difference in steady state levels of transcripts from rearranged and unrearranged $\mathrm{V}$ genes could reflect a difference in transcription rate and/or a difference in turnover rates of the two types of transcripts. The large difference in steady state levels suggests that the rate of transcription is a major factor, especially since the rate of processing and transport of immunoglobulin transcripts is thought to be rapid (18). To prove that this is in fact the case we made direct assays of transcriptional activity in isolated myeloma nuclei. In preliminary experiments we had difficulty in preparing an active nuclear system from plasmacytomas such as PC 4050 and MOPC 321 which are carried as subcutaneous tumors in mice. However, we had success with nuclei prepared from cultured myeloma cells. Therefore, for these experiments we chose the myeloma cell line S107.3, which contains two (30) or possibly three (31) rearranged $\kappa$ loci that produce $\kappa-$ mRNAs unrelated to the $v_{\kappa} 21$ group, and which has been shown to contain a full set of $V_{K} 21$ genes in the germline configuration (26). We confirmed this latter fact for our particular cell line by Southern blot analysis (data not shown), and hence could use the $v_{K} 21$ plasmid to measure transcriptional activity of unrearranged $v_{\kappa}$ genes. Since 
cloned sequences of the $v_{k}$ genes represented in the S107 mRNAs were not available, we used a cloned $C_{k}$ sequence to assay for the transcriptional activity of the rearranged genes. If there is uniform loading of polymerase II molecules over the rearranged $k$ loci, the use of $C_{k}$ or $V_{k}$ sequences should give equivalent results in this type of assay. Of course, the relative number of $C_{k}$ and $v_{k}$ genes must also be taken into account when interpreting the results (vide infra).

When pulse-labeled RNA from S107 nuclei was hybridized to Southern blots containing restriction fragments of the $C_{\kappa}$ and $V_{K} 21$ cDNA plasmids, the only fragment that hybridized was the 1280 bp band containing the $C_{k}$ sequences (Fig. 4a). The labeled RNA was also hybridized to dot blots of the linearized cDNA plasmids (Fig. 4b). A 23-hour autoradiogram showed a clear signal from the filter containing the $C_{k}$ plasmid whereas no signal was detected from the filter containing the $\mathrm{V}_{\mathrm{K}} 21$ plasmid or the pMB9 plasmid control. A 10-fold longer exposure detected a weak signal from the $v_{\kappa} 21$ plasmid. However, an even more

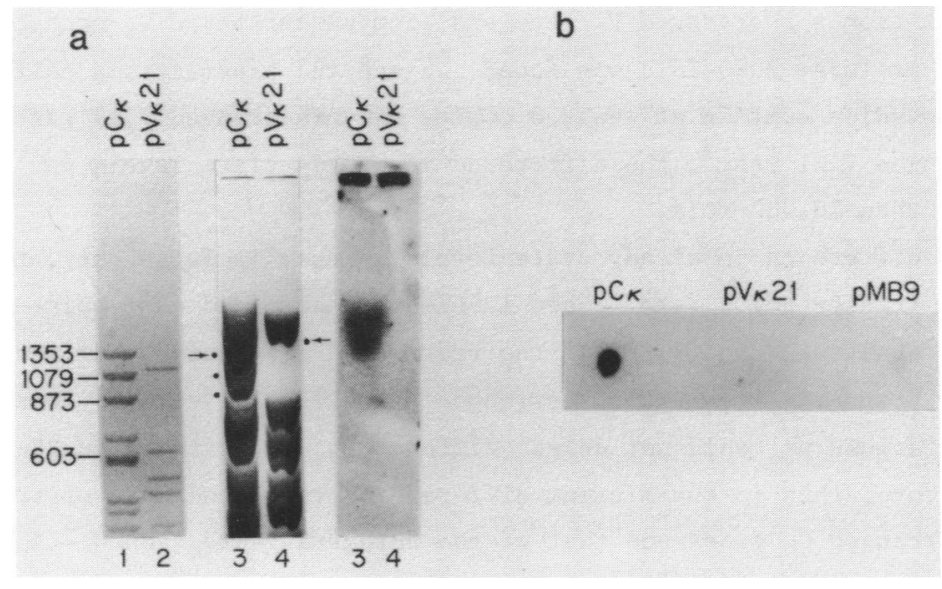

Figure 4 Analysis of pulse-labeled RNA. Nuclei from the S107.3 myeloma cell line were incubated with $32 \mathrm{P}$-UTP for $15 \mathrm{~min}$ as described in the Materials and Methods section. The RNA was isolated and hybridized to plasmid DNA that contained either $C_{K}$ or $V_{K} 21$ sequences. (a) Plasmid DNA was digested with Hha $I$, electrophoresed on $2 \%$ agarose gels, transferred to nitrocellulose paper and hybridized with the $32 \mathrm{P}-1$ abeled RNA. Lanes 1 and 3 were loaded with 1 and $20 \mu \mathrm{g}$ of the $\mathrm{C}_{K}$-containing plasmid and lanes 2 and 4 were loaded with 1 and $15 \mu \mathrm{g}$ of the $\mathrm{V}_{K} 21$-containing plasmid. The first four lanes show the ethidium bromide staining and the last two lanes show the autoradiograph. The points mark the leading edge of the bands in the overloaded lanes and the arrows indicate the bands that contain the $C_{K}$ and $V_{K} 21$ sequences. The $V_{K} 21$-containing band migrated slower than expected relative to the $C_{k}$ band, presumably as a result of concentration differences. (b) Twenty micrograms of the $C_{k}$ plasmid and $15 \mu g$ of the $\mathrm{V}_{K}$ plasmid were digested with Bam HI, spotted onto nitrocellulose, and hybridized with the 32P-labeled RNA. The autoradiogram shown was exposed for 4 days. 
intense signal was detected from the PMB9 control suggesting some nonspecific retention of radioactivity on the filters. The transcription reaction was carried out in the presence of Sarkosyl, which inactivates free RNA polymerase and removes many non-histone proteins from chromatin without affecting RNA polymerase II transcription complexes (32). Thus, these results indicate that RNA polymerase is not productively bound to unrearranged $\mathrm{V}_{\kappa} 21$ genes. Although the transcription assay is not as sensitive as the solution hybridization assays, it is clear that difference in the transcription rate is a major factor in determining the difference in steady state levels of RNA transcribed from rearranged and unrearranged $\mathrm{V}$ genes.

\section{DISCUSSION}

$V_{K}$ genes in the rearranged configuration are actively transcribed in myeloma cells. In contrast, we have found that $v_{K}$ genes in the unrearranged or germline configuration are either not transcribed or transcribed at extremely low levels. When nuclear RNA was assayed for steady state levels of transcripts from a rearranged $v_{K}$ gene and from unrearranged $v_{K}$ genes, a difference of at least 2000-fold was found. Since the plasmacytoma cells used for these studies contain at least 8 copies of unrearranged $v_{\kappa} 19$ gene and only one rearranged $V_{K} 21$ gene*, the difference in steady state levels per $V$ locus is greater than $16,000-$ fold.

The difference in steady state levels is due, in large part, to a difference in transcription rate. When labeled RNA obtained from pulse-labeled nuclei was assayed, transcripts of the rearranged gene were readily detected whereas no transcripts of the unrearranged genes were detected. Because of noise limitations we could not detect differences of greater than 25-fold, and, therefore, this is the minimum difference between the rate of transcription of the rearranged $C_{k}$ genes and that of the unrearranged $V_{k}$ genes. Again, when expressed per gene, the difference is greater. Assuming that the myeloma used for these experiments has three rearranged $C_{k}$ genes (31), all of which are transcribed and would be detected with the probe employed, and a haploid set of eight $\mathrm{V}_{K} 21$ genes in the germline configuration, the difference in transcription rate of the rearranged and unrearranged $V$ genes per locus would be at least $(8 / 3) 25$ or $70-$ fold. Taken together, the steady state measurements and the pulselabel data indicate that transcription of unrearranged $\mathrm{V}$ genes is insignificant. Indeed, it is highly probable that there is no transcription of unrearranged $\mathrm{V}$ genes.

What is the molecular basis of this regulatory phenomenon? It has been reported that an unrearranged $V_{k}$ gene is resistant to DNase I digestion, whereas 
the same gene in the rearranged configuration is sensitive (33). Thus, $V_{K}$ genes appear to conform to the pattern observed with other tissue-specific genes: inactive genes are relatively insensitive to DNase I digestion and active genes are sensitive (34). This suggests that rearrangement of a V gene is accompanied by an alteration in its chromatin structure. If the elements that control $\mathrm{V}$ gene transcription were located exclusively in the $5^{\prime}$ flanking regions, there would have to be a mechanism by which the particular 5' element associated with the rearranged $V$ gene would undergo a heritable modification in chromatin structure during the process of rearrangement. Inasmuch as the transcriptional initiation site is over 500 nucleotides from the recombination site (15), such a mechanism, although possible, is not easy to envisage. On the other hand, one can readily imagine a mechanism in which sequences $3^{\prime}$ to the $V_{k}$ genes inhibit $V_{K}$ gene transcription in a manner analogous to the proposed regulation of the fetal $\beta$ globin genes associated with hereditary persistence of fetal hemoglobin $(6,7)$. Because the rearrangement that produces a complete $\kappa$ gene deletes sequences $3^{\prime}$ of the expressed $V_{K}$ gene (35), the inhibitory element would be lost when a $k$ gene was formed.

An alternative hypothesis, which we find attractive, is that it is the proximity to the $C_{k}$ locus which actually confers transcriptional competence on the $\mathrm{V}_{K}$ gene. In B-lymphoid cells the germline $\mathrm{C}_{K}$ locus is constitutively transcribed beginning in an upstream region which resembles the 5' flanking regions of $V_{K}$ genes $(15,36)$. Rearrangement results in the replacement of this region by a $\mathrm{V}$ gene which then becomes active in initiating transcription. Conceivably, an interaction between regions $5^{\prime}$ of the $v_{k}$ gene and $3^{\prime}$ of the $C_{K}$ gene could create and maintain a transcriptionally active chromatin domain.

This general system of transcriptional regulation seems particularly well-suited to a large multigene family like the immunoglobulin $\mathrm{V}$ genes, in which all functional members of the family must be potentially transcribable in the same state of cellular differentiation, but in which only one member per allele is active in any given cell. This system might sacrifice some apparently useless transcription of a single $C_{K}$ locus in order to avoid the much greater wastage that would ensue if the several hundred unrearranged $V$ genes were also transcribed.

\section{ACKNOWLEDGMENTS}

This work was supported by a grant from the National Science Foundation (PCM80-10972), grants from the National Institutes of Health (AI-17330, CA-06927 and RR-05539), a fellowship from the Cancer Research Institute, and an appro- 
priation from the Commonwealth of Pennsylvania.

\section{FOOTNOTE}

${ }^{*}$ Although the cell contains additional $v_{\kappa} 21$ genes in the germline context, the level of transcription of these genes would presumably be similar to that of the unrearranged $\mathrm{V}_{\mathrm{K}} 19$ genes.

\section{REFERENCES}

1. Lewin, B. (1980) in Gene Expression, Vo1. II, p. 950, J. Wiley and Sons, New York.

2. Grossched1, R. and Birnstiel, M. L. (1980) Proc. Nat1. Acad. Sci. USA 77, 7102-7106.

3. Wasylyk, B., Derbyshire, R., Guy, A., Molko, D., Roget, A., Teoule, R. and Chambon, P. (1980) Proc. Nat1. Acad. Sci. USA 77, 7024-7028.

4. Sakonju, S., Bogenhagen, D. F. and Brown, D. D. (1980) Cel1 19, 13-25.

5. Hofstetter, H., Kressmann, A. and Birnstiel, M. L. (1981) Cel1 24, 573-585.

6. Bernards, R., Kootei, J. M. and Flave11, R. A. (1979) Gene 6, 265-280.

7. Fritsch, E. F., Lawn, R. M. and Maniatis, T. (1979) Nature 279, 598-603.

8. Long, E. O., Rebbert, M. L. and Dawid, I. B. (1981) Proc. Nat1. Acad. Sci. USA 78, 1513-1517.

9. Bentley, D. L. and Rabbitts, T. H. (1980) Nature 288, 730-733.

10. Huang, H., Crews, S. and Hood, L. (1981) J. Molecular and Applied Genetics 1, 93-101.

11. Kabat, E. A., Wu, T. T. and Bilofsky, H. (1979) in Sequences of Immunoglobulin Genes. NIH Publication No. 80-2008.

12. Peck, M., Hocht1, J., Schne11, H. and Zachau, H. G. (1981) Nature 291, 668-670.

13. Lenhard-Schuller, R., Hohn, B., Brack, C., Hirama, M. and Tonegawa, S. (1978) Proc. Nat1. Acad. Sci. USA 75, 4709-4713.

14. Wilson, R., Miller, J. and Storb, U. (1979) Biochemistry 18, 5015-5021.

15. Perry, R. P., Kelley, D. E., Coleclough, C., Seidman, J. G., Leder, P., Tonegawa, S., Matthyssens, G. and Weigert, M. (1980) Proc. Natl. Acad. Sci. USA 77, 1937-1941.

16. Marcu, K. B., Valbuena, 0. and Perry, R. P. (1978) Biochemistry 17, 1723-1733.

17. Perry, R. P., LaTorre, J., Kelley, D. E. and Greenberg, J. R. Biochim. Biophys. Acta 262, 220-226.

18. Schibler, U., Marcu, K. B. and Perry, R. P. (1978) Cell 15, 1495-1509.

19. Thomas, P. S. (1980) Proc. Nat1. Acad. Sci. USA 77, 5201-5205.

20. Rabbitts, T. H., Matthyssens, G. and Hamlyn, P. H. (1980) Nature 284, 238-243.

21. Tata, J. R. (1974) Meth. Enzymol. 31, 253-262.

22. McKnight, G. S. and Palmiter, R. D. (1979) J. Biol. Chem. 254, 9050-9058.

23. Groudine, M., Peretz, M. and Weintraub, H. (1981) Molec. and Cell. Biol. $1,281-288$.

24. Kafatos, F. C., Jones, C. W. and Efstratiadis, A. (1979) Nucl. Acids Res. 7, 1541-1552.

25. Birnstiel, M. L., Sells, B. H. and Purdom, I. F. (1972) J. Mol. Biol. $63,21-39$.

26. Seidman, J. G., Nau, M. M., Norman, B., Kwan, S.-P., Scharff, M. D. and Leder, P. (1980) Proc. Nat1. Acad. Sci. USA 77, 6022-6026. 
27. Valbuena, 0., Marcu, K. B., Weigert, M. and Perry, R. P. (1978) Nature 276, 780-784.

28. Cory, S., Tyler, B. M. and Adams, J. M. (1981) J. Mo1. App1. Genet. 1, 103-116.

29. Selsing, E. and Storb, U. (1981) Nuc1. Acids Res. (in press).

30. Kwan, S.-P., Max, E. E., Seidman, J. G., Leder, P. and Scharff, M. D. (1981) Cell 26, 57-66.

31. Bernard, O., Gough, N. M. and Adams, J. M. (1981) Proc. Nat1. Acad. Sci. USA 78, 5812-5816.

32. Gariglio, P., Buss, J. and Green, M. H. (1974) FEBS Letters 44, 330-333.

33. Storb, U., Wilson, R., Selsing, E. and Walfield, A. (1981) Biochemistry 20, 990-996.

34. Mathis, D., Oudet, P. and Chambon, P. (1980) Prog. Nucl. Acids Res. Molec. Biol. 24, 1-55.

35. Seidman, J. G., Max, E. E. and Leder, P. (1979) Nature 280, 370-375.

36. VanNess, B., Weigert, M., Coleclough, C., Mather, E.L., Kelley, D.E. and Perry, R. P. (1981) Cell (In press). 